This genus is allied to Salea, from which it differs in its gular sac ; it has more the aspect of the Ceylonese Cophotis, from which, however, it is further removed by its naked tympanum.

9. Descriptions of new Uropeltidæ from Southern India, with Remarks on some previously-described Species. By Lieut.-Colonel R. H. Bedpome, C.M.Z.S.

[Received January 12, 1878.]

Silybura Nigra, n. sp.

Snout short, slightly pointed, rostral not nearly separating the nasals; eye very small, in the front part of the ocular shield, no supraorbital; scales all in nineteen rows, abdominals 180-185, caudal disk convex, not well defined, scales slightly keeled, subcaudals six to nine pairs, terminal scute of tail bicuspid ; body black, very iridescent, with irregular transverse rows of yellowish-white spots, a yellowish streak commences at the fourth labial and extends along the sides for 1 to 2 inches, sides and belly more or less blotched with broad transverse patches of yellow, the first one or two inches of the belly generally uniform black.

Hab. Pulney Mountains, $4000 \mathrm{ft}$. elevation.

Silybura Nitida, n. sp.

Snout obtusely pointed; rostral very small, not nearly separating the nasals ; eye small, in the front part of the ocular shield ; no supraorbital ; fourth upper labial reddish yellow, caudal disk convex, indistinct; scales three to six ; keeled terminal scute rather large, not laterally compressed, bicuspid, the points side by side, scales in seventeen rows, abdominals 188 to 194 . Colour nearly jet-black, but very iridescent; the belly with very distant large reddish-yellow blotches, the black colour much predominating.

$H a b$. Anamallays, 4000 to $5000 \mathrm{ft}$.

Silybura Petersi, n. sp.

Snout obtuse ; rostral very small, not separating the nasals; tail laterally compressed, caudal disk not defined; the scales nearly quite smooth or faint traces of keels, the terminal scute shovel-shaped, not bicuspid; eye very small, in the front part of the ocular shield; no supraorbital; abdominals 155 to 158 ; subcaudals ten to twelve pairs; scales in seventeen rows; above uniform brown; sides with indistinct yellowish white spots or narrow transverse bars, which sometimes extend across the belly; a broad yellowish patch across the vent.

$H a b$. Anamallays, $4000 \mathrm{ft}$. Rare; a small species.

\title{
Silybura maculata, n. sp.
}

Snout obtuse ; rostral very smali, not separating the nasals, which are as large as the frontals; eye rather large, in the front part of the ocular shield; no supraorbital; tail laterally compressed, not well defined; caudal disk without keels, but a few of the terminal scales a little rugose, terminal scale slightly bicuspid, the points side by 
side. Scales round the body in seventeen rows, abdominals about 156, subcaudals eight to thirteen pairs. Colour of a uniform brown or sometimes quite black, with several deep-red blotches along the sides of the anterior portion of the trunk and about the tail, and rarely several of these are present along the sides of the trunk.

Hab. —?

The tail of this species is more like that of Plectrurus than that of Silybura; but I prefer to restrict Plectrurus to those species which have a supraorbital shield and only fifteen rows of scales.

The snake I formerly described as Plectrurus trilineatus has been placed by Dr. Günther in a new genus, "Platyplectrurus:" this has the supraorbital and only fifteen rows of scales, but it differs from Plectrurus proper in the presence of an elongated temporal shield over the fourth labial, besides in other points, as noted by Dr. Günther; and I think the genus may stand. Plectrurus sanguineus (which I find, on a reexamination of the species, has always fifteen rows of scales only round the centre of the body, not seventeen) will belong to this genus; and I have described two other species, $P$. hewstoni and $P$. madurensis.

My Plectrurus pulneyensis has been placed by Dr. Günther in Rhinophis; but it should, I think, rather be referred to Silybura.

My Silybura canarica has been referred to Plectrurus: it has only fifteen rows of scales (but it wants the supraorbital); the tail, however, is exactly that of the type of Plectrurus, with the points of the terminal scutes one above the other. It may form a distinct section in the genus, or have a new genus constituted for it. The only other Silybura described with fifteen rows of scales is Silybura macrolepis of Peters, which I have never seen, and its locality is unknown; it has evidently the typical caudal disk of Silybura. Dr. Günther omits all mention of this species in his synopsis of the species published in the Society's 'Proceedings' in March 1875.

I wish that I could attach the same importance as Dr. Günther does to the number of the abdominal plates; if he is correct in this, I have several new species of the ocellated Silyburce like S. ocellata, liura, and melanogaster.

Specimens of all the species described in this paper have been sent to the British Museum.

\section{On the Larina or Gulls. By Howard Saunders, F.L.S., F.Z.S.}

[Received December 31, 1877.]

A revision of the Larince is a more difficult task than that of the Sternina, the members of the present subfamily being subject to far greater variations in piumage on their passage from youth to age than is customary with the Terns. The latter, although offering differences in individual size and graduation of tint which are often extremely puzzling, may be said to have only two, or at most three, stages of plumage, viz. the immature, the winter-, and the adult 


\section{$2 \mathrm{BHL}$ Biodiversity Heritage Library}

Beddome, R. H. 1878. "Descriptions of new Uropeltidae from Southern India, with remarks on some previously described species." Proceedings of the Zoological Society of London 1878, 154-155.

View This Item Online: https://www.biodiversitylibrary.org/item/90438

Permalink: https://www.biodiversitylibrary.org/partpdf/67223

\section{Holding Institution}

Natural History Museum Library, London

\section{Sponsored by}

Natural History Museum Library, London

\section{Copyright \& Reuse}

Copyright Status: Public domain. The BHL considers that this work is no longer under copyright protection.

This document was created from content at the Biodiversity Heritage Library, the world's largest open access digital library for biodiversity literature and archives. Visit BHL at https://www.biodiversitylibrary.org. 